\title{
Seismic Vertical Component Effects on Seismic Demands of a Base Isolated Bridge with Friction- Rubber Bearings
}

\author{
Afshin Kalantari* and Seyyed Amirhossein Moayyedi \\ International Institute of Earthquake Engineering and Seismology, Iran
}

Submission: November 18, 2017; Published: February 26, 2018

*Corresponding author : Afshin Kalantari,Structural Engineering Research Center, International Institute of Earthquake Engineering and Seismology, Iran, Tel:22830830; Email : a.kalantari@iiees.ac.ir

Abstract

Past experiences regarding the near-fault effect of earthquakes have shown a potentially significant effect of vertical component on the response of bridges and their seismic equipment. In this study, a friction-rubber hybrid isolator was designed for a highway bridge and modeled to evaluate the effect of vertical seismic component on the performance of isolators in a concrete bridge. Numerical study on the bridge was conducted under two conditions:

i. With only two horizontal seismic components, and

ii. With three seismic components (including the vertical component).

For this purpose, finite element model of the structure was developed in Open Sees software and then subjected to nonlinear dynamic analysis under 29 different ground motion records. The results showed that maximum shear and axial force in the isolator elements undergo significant increase under all seismic excitations. Due to the absence of self-restoring force in the studied isolator, the permanent and maximum deck displacement increased during some of the earthquake records, and in a few cases, the permanent displacements of the deck were particularly significant. The axial forces of the isolators on the base and abutment were found to be correlated with the spectral acceleration at the period of vibration mode effective in vertical direction.

Keywords: Seismic isolation; Vertical component; Time history analysis; Highway bridge

\section{Introduction}

The growth of urban population and industrial activities and their steadily increasing transportation requirements have led to a widespread construction and use of highway structures in and around major cities. Bridges play an essential role in transportation networks specify after earthquakes. Given the vital role of these structures in transportation systems, ensuring their safety and optimal seismic performance is of significant importance. Base isolation systems can protect the superstructure against earthquake damage by decoupling it from the substructure and thus from the seismic load. Such seismic load reduction scheme largely depends on proper function of isolation units. Thus, factors associated with the performance of isolators are of significant importance for the seismic performance of structure and have to be evaluated under different seismic excitation. Vertical components and strong pulse motion of ground motions are among the factors that may adversely affect the performance of a bridge isolation system, especially in near-fault areas. In particular, this component can undermine the performance of friction isolators operating alone or in combination with rubber bearings. In such isolators, variation in axial force between the two sliding pads may induce instability in the energy dissipation process and cause erratic isolation performance, and thereby affect the relative displacement and shear response of the device and structure. Figure 1 shows a friction-rubber hybrid bearing in a bridge with box girder deck.

The effects of vertical seismic component on bridges with or without seismic isolation systems have been extensively researched. Some of these studies have emphasized the consequences of ignoring the vertical component in the nearfault structures. Papazoglou \& Elnashai [1] have provided both analytical and field evidence supporting the damaging effects of vertical seismic component on buildings and bridges. They expressed that significant fluctuation in the axial force of vertical components leads to a reduction in the shear capacity 


\section{Civil Engineering Research Journal}

of columns. Gloyd [2] developed a design criteria by studying 60 pre stressed box girder bridges with due attention to the effect of vertical seismic component. Design values considered for the vertical shear force in deck and flexural moment in two main spans of these bridges indicate that dynamic response induced by vertical acceleration is much larger than the effect of dead load. Kunnath et al. [3] the effect of vertical seismic component on the seismic design recommended by Caltrans (Caltrans Seismic Design Criteria) regulation was investigated on multiple conventional bridges. The results of this study showed that Caltrans regulations have a poor accuracy and cannot account for the changes made by the vertical ground motion component in the axial force of column and the mid-span moment. Rahayi \& Arezumandi [4] studied the effects of vertical seismic component on the bridge piers using the seismic records of Tabas 1978, Northridge 1994 and Kobe 1995 earthquakes. They reported that the presence of vertical component increases the axial force as well as axial and shear strain, but the consequent changes in shear force and longitudinal displacement are negligible. However, due to absence of seismic isolators in the structures examined in the aforementioned studies, their results cannot be relied upon to explain the seismic behavior in the presence of isolators.

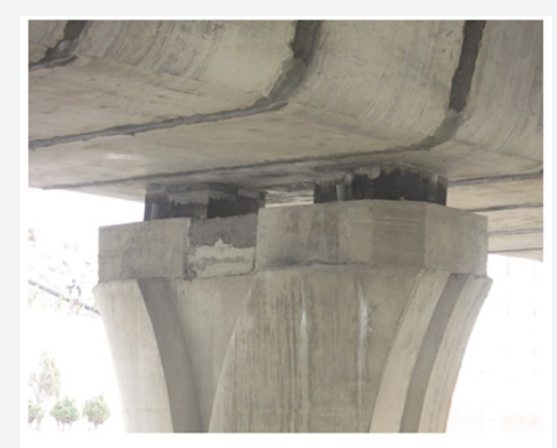

Figure 1: Sliding-rubber bearings used on the highway bridge.

A number of researches have focused specifically on the effect of vertical seismic component on the isolator behavior. For example, Naeim \& Kelly [5] investigated the relationship of horizontal and vertical stiffness with vertical load and lateral deformation respectively, and reported that increase in vertical load and lateral deformation leads to a decrease in vertical and horizontal stiffness respectively. Nakajima et al. [6] using experimental model and numerical analysis examined the effects of vertical seismic component on the bridge piers equipped with isolation systems. Considering the effects of vertical seismic component on the variation in the axial force of isolator component, they reported that these changes have no significant effect on response values. Nevertheless, they emphasized that when evaluating the performance of a base isolated bridge under vertical seismic component, changes in the friction coefficient should be duly considered. Iemura et al. [7] studied the effect of vertical acceleration on the seismic performance of Japanese highway bridges under four seismic events. The results showed that vertical seismic component has a substantial effect on the response of isolation systems. In a study by Mazza \& vulcano [8] on the response of a building resting on different hybrid isolators and subjected to all three seismic components, it was found that due to a longer natural period, the adoption of a frictionrubber system proves effective for controlling the damage of $\mathrm{RC}$ frame members. However, these researchers did not investigate the behavior of such systems affected by ground motions with significantly large vertical components. Warren et al. [9] investigated the effect of vertical seismic load on the low damping lead-rubber bearings in bridges, the results showed that vertical stiffness of isolation systems should not be ignored. In another study, Reyhanoğullari [10] studied the effect of vertical seismic component of seven accelerogram records on steel bridges with and without base isolation. They used numerical model of leadrubber bearings in the study. The results of this study showed an increase in responses and their correlation with defined criteria. Wang C et al. [11] investigated the effects of vertical excitation on the seismic performance of a seismically isolated bridge with sliding friction bearings. Different bearing friction coefficients and different stiffness levels (pier diameter) were discussed in the paper. The study results showed that vertical excitation had a relatively large impact on seismic performance for a seismically isolated bridge with sliding friction bearings where vertical excitation dominates.

Review of aforementioned studies shows the importance of the vertical component effects on behavior of base isolated bridges and absence of a detailed investigation on the seismic behavior of hybrid friction-rubber isolators under seismic excitations with significant vertical component. To address this issue, in this paper, a numerical model was developed to investigate the performance of the structure by nonlinear time history analysis.

To determine the relationship of vertical acceleration with the axial force of isolator, the relationship between the response values and their corresponding spectral values along vertical direction was investigated. Moreover, since the seismic performance of a bridge largely depends on the performance of its seismic equipment, the effect of vertical earthquake component on the seismic response of hybrid isolator was studied. To find out the mentioned relationship and the performance of the isolator, first, a friction-rubber hybrid isolator was designed according to the AASHTO (American Association of State Highway and Transportation Officials, Guide Specifications for Seismic Isolation Design, 2010) recommendations [12]. A threedimensional model of the bridge was then developed in the finite element Open Sees software [13]. Finally, the effect of vertical seismic components on the response parameters of the bridge and isolators was investigated under two groups of dynamic analysis: A group with only two horizontal seismic components; and another with two horizontal along with vertical component. 


\section{Civil Engineering Research Journal}

\section{Bridge Specifications and Numerical Model}

For the purpose of numerical study, a continuous bridge consisting of two 25-meter spans. The deck was employed includes 5 girders and a concrete slab of $20 \mathrm{~cm}$ thickness. In addition, the single pier comprises of 3 columns with beanshaped cross-sections connected to the cap-beam. The girders attach to the abutments and middle pier using a concrete diaphragm to allow for an integrated performance. Three isolators are installed in each of the abutments as well as the middle pier below the concrete diaphragm on the cap-beams. The soil-structure interactions in the foundation and abutment were ignored. The main components of the bridge and its isolated view are illustrated in Figure 2. In this study, an elastic a stick model was employed to simulate the bridge deck [14]. The command "Uniaxial Material Concrete01" was used to model the confined concrete, as well as the cover or unconfined concrete.
This command for uniaxial concrete materials utilizes the degrading linear unloading/reloading stiffness model developed by Kent and Park $[15,16]$. In unconfined concrete, strain is taken as 0.002 and 0.006 for maximum strength and crushing strength, respectively. In Confined concrete, strain of 0.005 and 0.05 occur at maximum strength of $26.5 \frac{\mathrm{N}}{\mathrm{mm}^{2}}$ and crushing strength of 25 $\frac{N}{m^{2}}$, respectively. A uniaxial material with a bilinear stressstrain behavior is considered for the reinforcement. Yield stress was taken as $392.266 \frac{\mathrm{kg}}{\mathrm{cm}^{2}}$ with a strain-hardening ratio of 0.01
(Figure 3).

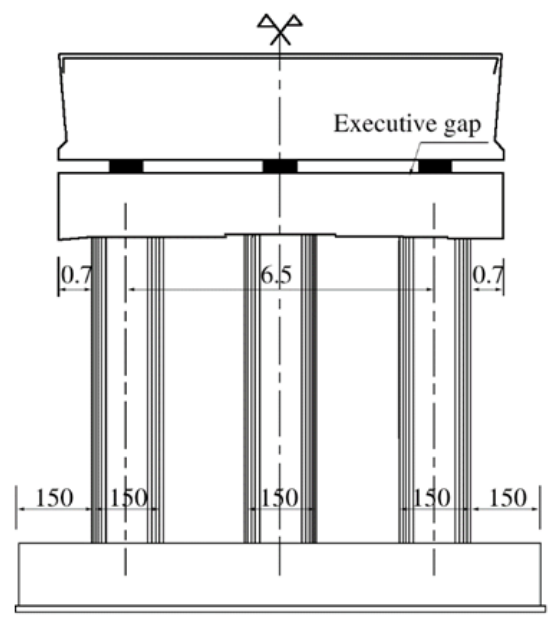

(a)

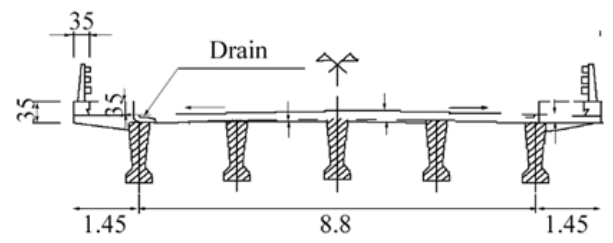

(b)

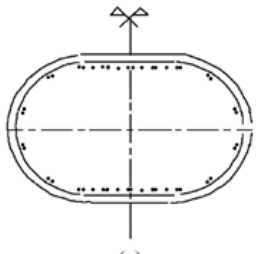

(c)

Figure 2: Main components of the bridge (a) Pier (b) Girders (c) Section of column.
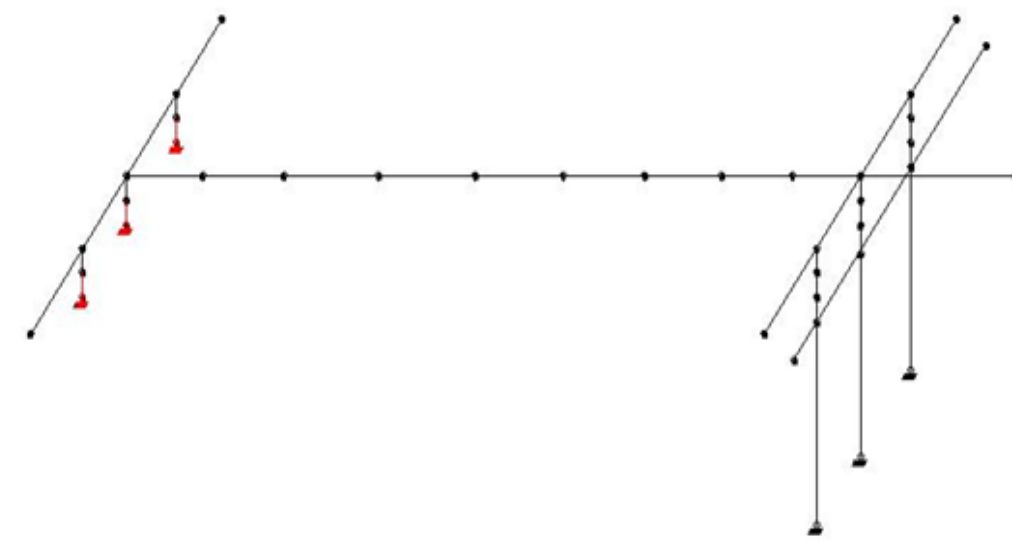

Figure 3: Numerical model of isolated bridge. 


\section{Civil Engineering Research Journal}

The isolator consists of a rubber bearing attached to slider steel plates whose contact surface is coated by Polytetrafluoroethylen (PTFE). Figure 4a demonstrates the logic model and nonlinear behavior considered for the isolators. A schematic view of the hybrid isolators employed in this study is shown in Figure 4b. The initial stiffness in nonlinear behavior of device is provided by rubber pad which deflects until the restoring force reaches the limit required for the slider part to move. Equation 1 describes the friction force $\left(\mathrm{F}_{\mathrm{b}}\right)$ as a function of mass, gravitational acceleration and ground vertical acceleration at the time of earthquake. (Figure 4c)

$$
F_{b}=\mu \cdot m\left(g \pm \ddot{u}_{y}\right)
$$

Two types of these isolators were designed, the specifications for which are given in Table 1.

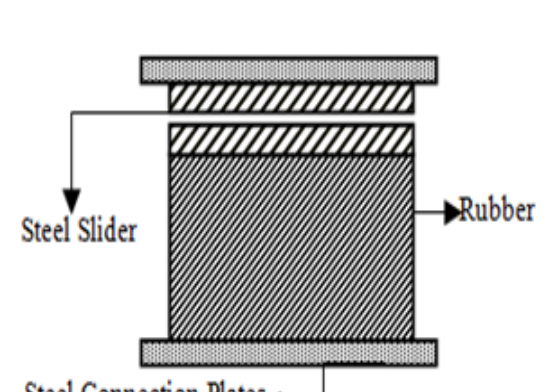

Steel Connection Plates

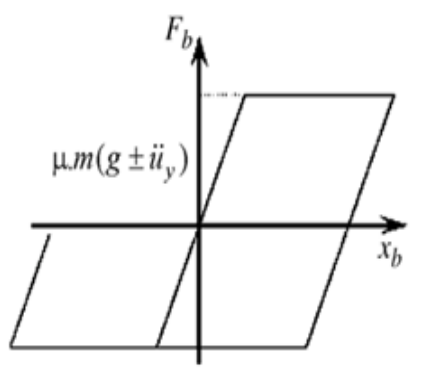

(b)

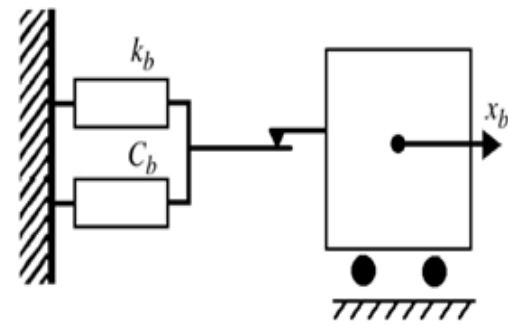

(c)

Figure 4: Numerical model of isolated bridge.

Table 1: Specification of isolators.

\begin{tabular}{|c|c|c|c|}
\hline & Demension(m) & Ki (N/m) & $\begin{array}{c}\text { dy } \\
(\mathrm{m})\end{array}$ \\
\hline Isolators on pier & $0.7 * 0.7 * 0.16$ & 7453628 & 0.02 \\
\hline Isolators on abutments & $0.7 * 0.7 * 0.16$ & 2255500 & 0.02 \\
\hline
\end{tabular}

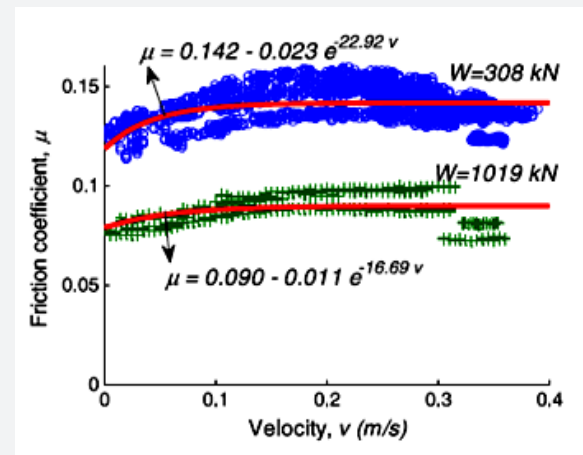

Figure 5: Variation of friction coefficient as a function of velocity [18].

The sliding velocity and instantaneous vertical force applied to the isolators change. Consequently, the vertical force or vertical acceleration directly affects the shear force acting upon the isolator. On the other hand, changes in both sliding velocity and instantaneous vertical force parameters cause variations to the coefficient of friction, which in turn changes the shear force. Hence, the proposed behavior model by Dao was used to model the coefficient of friction [18]. In this model, the coefficient of friction was experimentally calculated for different sliding velocities and 8 different vertical forces. Then, as demonstrated in Figure 5, the curve fitting was carried out based on the results. The coefficient is expressed according to Equation 2 as a function of the obtained minimum and maximum values [19].

$$
\mu=\mu_{\max }-\left(\mu_{\max }-\mu_{\min }\right) \exp ^{(- \text {aù })}
$$

Where, is the instantaneous velocity and a is an empirical parameter depending on the applied pressure as well as the conditions of sliding surfaces (Figure 6). Additionally, $\mu_{\max }$ and $\mu_{\text {min }}$ are the values of coefficient of friction obtained at maximum and minimum sliding velocities, which vary based on the vertical force. Variations in these two parameters were expressed by Bowden and Tabor through Equations 3 and 4, a diagram of which is depicted in Figure 7 [20].

$$
\begin{aligned}
& \mu_{\max }=A_{\max } W^{n_{\max }-1} \\
& \mu_{\min }=A_{\min } W^{n_{\min }-1}
\end{aligned}
$$

Where, $A_{\max }$ and $A_{\min }$ are constants, and $n_{\max }$ and $n_{\min }$ are empirically obtained coefficients with values smaller than 1 . 


\section{Civil Engineering Research Journal}

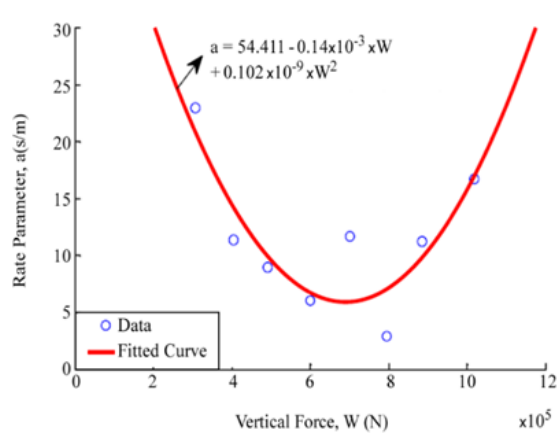

Figure 6: Rate parameter [17]

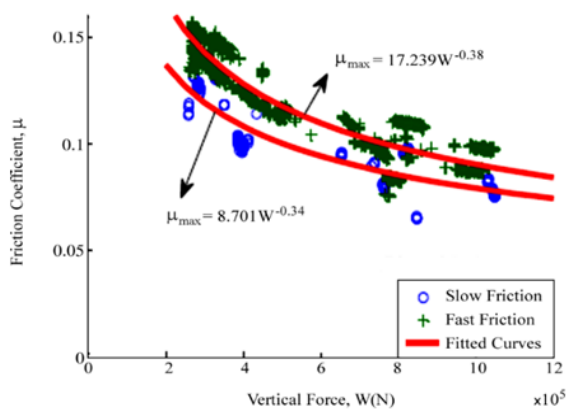

Figure 7: Friction coefficient vs vertical force [17].

\section{Buckling}

The relationships needed to check and control buckling of rubber are provided by Naeim \& Kelly [5]. The critical vertical load that can be sustained by an isolator can be obtained from Equation (5).

$P_{c r i t}=\sqrt{P_{S} \cdot P_{E}}=\sqrt{\left(G A \frac{h}{t_{r}}\right)\left(\frac{\pi^{2}}{h^{2}} \cdot \frac{1}{3} \cdot 6 G S^{2} A r^{2} \frac{h}{t_{r}}\right)}=\frac{\sqrt{2} \pi G A S r}{t_{r}}$

Where $P_{S}$ is the shear stiffness per unit length of the isolator, $P_{E}$ is the Euler buckling load, $\mathrm{G}$ is the shear modulus, A is the cross sectional area, $\mathrm{S}$ is the shape factor (for a square seat

$S=\frac{a}{4 t}$ ), $\mathrm{r}$ is the radius of gyration (for a square seat $r=\frac{a}{2 \sqrt{3}}$ ) $\mathrm{h}$ is the total height of the isolator (rubber and steel $t_{r}$ ), and is the total height of rubber.

\section{Seismic Input}

In this study, 29 earthquake acceleration records with considerable vertical components were selected from [21]. Specifications of the accelerograms applied in this study are given in Table 2.

Table 2: List of ground motion records.

\begin{tabular}{|c|c|c|c|c|c|c|c|}
\hline No. & Earthquake & Year & Station & $\mathbf{M}_{\mathbf{w}}$ & $\begin{array}{c}\text { Distance } \\
(\mathbf{K m})\end{array}$ & Site Class & PGA (g) \\
\hline 1 & Duze,Turkey(Bolu) & 1999 & Bolu & 7.1 & 12.04 & $\mathrm{D}$ & 0.71 \\
\hline 2 & Duze, Turkey(Lamont 375) & 1999 & Lamont 375 & 7.1 & 3.93 & $\mathrm{C}$ & 0.66 \\
\hline 3 & Gazli, USSR & 1976 & Karakyr & 6.8 & 5.46 & $\mathrm{C}$ & 0.68 \\
\hline 4 & Imperial (Bonds Corner) & 1979 & Bonds Corner & 6.5 & 2.68 & $\mathrm{D}$ & 0.52 \\
\hline 5 & Imperial (El Centro \#8) & 1979 & El Centro Array \#8 & 6.5 & 3.86 & $\mathrm{D}$ & 0.51 \\
\hline 6 & Kobe, Japan(Nishi-Akashi) & 1995 & Nishi-Akashi & 6.9 & 7.08 & $\mathrm{C}$ & 0.69 \\
\hline 7 & Kobe, Japan(Takarazuka) & 1995 & Takarazuka & 6.9 & 0.27 & $\mathrm{D}$ & 0.76 \\
\hline 8 & Landers & 1992 & Lucerne & 7.3 & 2.19 & $\mathrm{C}$ & 0.56 \\
\hline 9 & Loma Prieta (Corralitos) & 1989 & Corralitos & 6.9 & 3.85 & $\mathrm{C}$ & 0.58 \\
\hline 10 & Loma Prieta (LGPC) & 1989 & LGPC & 6.9 & 3.88 & $\mathrm{C}$ & 0.71 \\
\hline 11 & Mammoth Lakes & 1980 & Long Valley Dam & 5.9 & 14.04 & $\mathrm{D}$ & 0.61 \\
\hline 12 & Manjil, Iran & 1990 & Abbar & 7.4 & 10 & $\mathrm{C}$ & 0.51 \\
\hline 13 & Morgan Hill & 1984 & Coyote Lake Dam_SW Abut_ & 6.2 & 0.53 & $\mathrm{C}$ & 0.96 \\
\hline 14 & N. Palm Springs(Noth Palm) & 1986 & North Palm Springs & 6.1 & 4.04 & $\mathrm{D}$ & 0.64 \\
\hline 15 & N. Palm Springs(Whitewater) & 1986 & Whitewater Trout Farm & 6.1 & 6.04 & $\mathrm{D}$ & 0.55 \\
\hline 16 & Nahanni, Canada & 1985 & Site 1 & 6.8 & 9.6 & $\mathrm{C}$ & 1.04 \\
\hline 17 & Northridge-01 (Beverly Hills) & 1994 & Beverly Hills-12520 Mulhol & 6.7 & 18.36 & $\mathrm{C}$ & 0.52 \\
\hline 18 & Northridge-01 (Castaic) & 1994 & Castaic-Old Ridge Route & 6.7 & 19.72 & $\mathrm{C}$ & 0.54 \\
\hline
\end{tabular}




\section{Civil Engineering Research Journal}

\begin{tabular}{|c|c|c|c|c|c|c|c|}
\hline 19 & Northridge-01 (Newhall) & 1994 & Newhall-Fire Station & 6.7 & 5.92 & D & 0.59 \\
\hline 20 & ChiChi-Taiwan (CHY028) & 1999 & CHY028 & 7.6 & 3.14 & C & 0.79 \\
\hline 21 & Northridge-01 (Pardee-SCE) & 1994 & Pardee-SCE & 6.7 & 7.46 & D & 0.52 \\
\hline 22 & Northridge-01 (Rinaldi) & 1994 & Rinaldi Receiving Station & 6.7 & 6.5 & D & 0.63 \\
\hline 23 & Northridge-01 (Santa) & 1994 & Santa Monica City Hall & 6.7 & 16.45 & D & 0.57 \\
\hline 24 & Northridge-01 (Simi) & 1994 & Simi Valley-Katherine Rd & 6.7 & 13.42 & C & 0.75 \\
\hline 25 & Northridge-01 (Sylmar) & 1994 & Sylmar-Olive View Med FF & 6.7 & 5.3 & C & 0.71 \\
\hline 26 & Northridge-01 (Tarzana) & 1994 & Tarzana-Cedar Hill A & 6.7 & 15.6 & D & 1.33 \\
\hline 27 & Northridge-06 & 1994 & Rinaldi Receiving Station & 5.3 & 5.54 & D & 0.53 \\
\hline 28 & ChiChi-Taiwan (CHY029) & 1999 & CHY029 & 7.6 & 10.97 & C & 0.26 \\
\hline 29 & San Salvador & 1986 & Geotech Investig Center & 5.8 & 6.3 & C & 0.54 \\
\hline
\end{tabular}

All ground motion records were scaled to fit the local horizontal acceleration ratio, this ratio was also multiplied by spectrum and regulations as specified by ASCE (American the vertical accelerations. Figure 8 show the scaled combined Society of Civil Engineers, Seismic Evaluation of Existing horizontal spectra and vertical spectra, respectively. Buildings, 2014) [22]. To maintain a fixed maximum vertical to

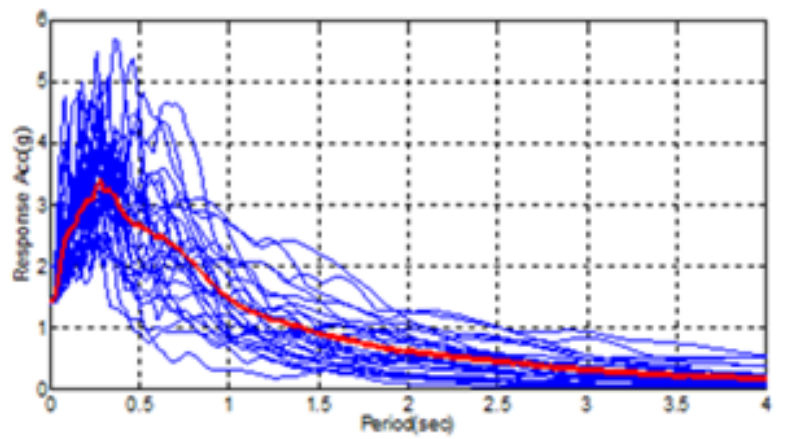

(a) Combination spectra of horizontal components (SRSS) and average of spectra

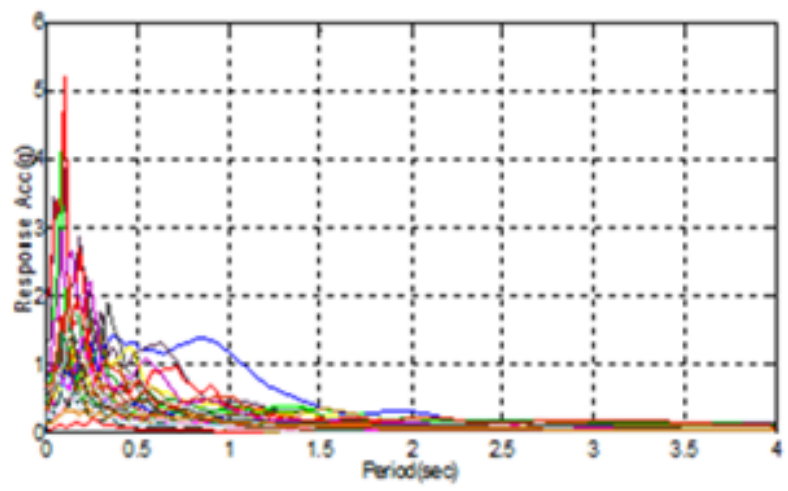

(b) Vertical spectra

Figure 8: Combination spectra of horizontal components and Vertical spectra. 


\section{Civil Engineering Research Journal}

\section{Validation}

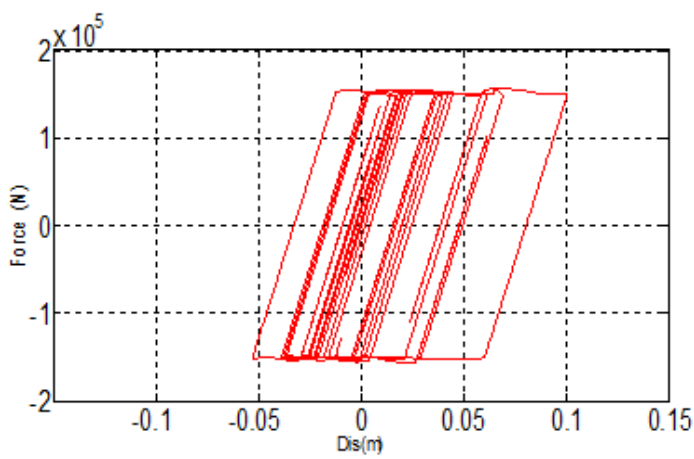

Figure 9: Hysteresis curves for the isolator element on the pier.

As can be seen, the differences between force and displacement values obtained from the model and analysis are reasonably small and can verify the validity of the model. Figures 9 \& 10 show the force-displacement curves of the isolators seated on the base and the abutment, which were obtained from numerical analysis of the bridge subjected to the Imperial Valley-06 (Bonds corner) ground motions applied along its transverse direction. The yield displacement and isolator shear force are also shown in the Figure. The validity of the modeled isolator was verified by comparing the response with the input data. The input yield displacement (dy), initial stiffness (Ki), and

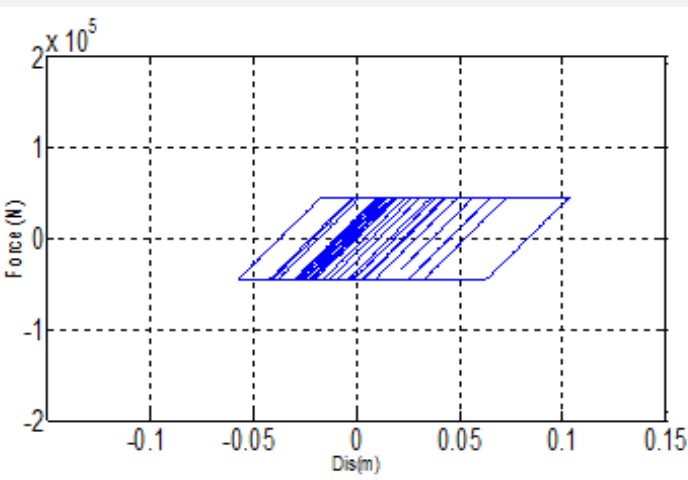

Figure 10: Hysteresis curves for isolator element on the abutment.

sliding force (Fy) values and the analysis results are given in Table 3. Since design and input data, were determined by assuming a constant friction coefficient, validation was performed using the Coulomb friction coefficient.

The $\frac{\text { Input }}{\operatorname{Re} \text { sult }}$ ratio of $K_{i}, d_{y}$ and $F_{y}$ for the isolator on the pier is $1,0.97$ and 0.98 , respectively. The corresponding values for the isolator on the abutment is 1 . An acceptable performance of the numerical analysis is observed in the analysis results shown in Table 3.

Table 3: Specification of isolators on the middle pier and abutments.

\begin{tabular}{|c|c|c|c|c|c|c|c|c|c|}
\hline & \multicolumn{3}{|c|}{ Ki (N/m) } & \multicolumn{3}{c|}{ dy (m) } & \multicolumn{3}{c|}{ Fy (N) } \\
\cline { 2 - 27 } & Input & Result & I/R & Input & Result & I/R & Input & Result & I/R \\
\hline Isolators on pier & 7453628 & 7453628 & 1 & 0.02 & 0.0205 & 0.97 & 149072.6 & 150604 & 0.98 \\
\hline Isolators on abutments & 2255500 & 2255500 & 1 & 0.02 & 0.02 & 1 & 45110 & 45016.3 & 1 \\
\hline
\end{tabular}

\section{Results of Numerical Analysis}

\section{Modal analysis}

Modal analysis was performed and the natural dynamic characteristics of the structure were calculated. The first three natural periods of the structure are presented in Table 4 .

Table 4: The first three natural period of the bridge structure.

\begin{tabular}{|c|c|}
\hline Mode No & T(sec) \\
\hline 1 & 1.03 \\
\hline 2 & 0.99 \\
\hline 3 & 0.84 \\
\hline
\end{tabular}

\section{Nonlinear time history analysis}

The effect of vertical seismic component on the base isolated bridge was investigated by computing the maximum response under two following conditions: i. 1-Under only two horizontal seismic components (without the vertical component)

ii. Under the three seismic components (two horizontal and vertical)

At each stage, the maximum response parameters under the above-mentioned condition were calculated and the effects of presence of vertical component on the response values were measured by the parameter $\alpha_{R}$, which is defined as:

$$
\alpha_{R}=\frac{R_{3 D}-R_{2 D}}{R_{2 D}} \times 100(6)
$$

Where, $R_{3 D}$ is the maximum response obtained from time history analysis in the presence of vertical component and $R_{2 D}$ 


\section{Civil Engineering Research Journal}

is the corresponding maximum response in the absence of vertical component are listed in Table 5. vertical component. The response parameters evaluated under

Table 5: Definitionof $\alpha_{R}$ for each of response parameters.

\begin{tabular}{|c|c|}
\hline aP-osI-F & Shear force of the isolator on the middle pier in transverse direction. \\
\hline aP-osI-D & The relative displacement of the isolator on the middle pier in transverse direction. \\
\hline areiP-N & The axial force of the isolator on the pier. \\
\hline aubA-N & The axial force of the isolator on the abutment. \\
\hline akceD-siD & Horizontal displacement of the deck in horizontal direction. \\
\hline akceD-siD-eR & The residual displacement of the deck in transverse direction. \\
\hline
\end{tabular}

The isolators on the abutment and deck have been indicated addition, summary of response parameters has been presented by Iso-A and Iso-B, in Figure 3, respectively. In the following the in Table 6.

results for each response parameter have been discussed. In

Table 6: A summary of response parameters resulted from analysis.

\begin{tabular}{|c|c|c|c|c|c|c|c|}
\hline No. & Earthquake & aP-osi-F & aP-osi-D & areiP-F-N & aubA-F-N & akceD-siD & akceD-siD-eR \\
\hline 1 & Duze,Turkey (Bolu) & 5.8 & 0.2 & 13.2 & 16 & 0.9 & 1.6 \\
\hline 2 & $\begin{array}{c}\text { Duze, Turkey (Lamont } \\
\text { 375) }\end{array}$ & 6 & 2.2 & 15.7 & 17.8 & 3.3 & 9.5 \\
\hline 3 & Gazli, USSR & 29.8 & 1.5 & 102.4 & 113.2 & 2.1 & 0.5 \\
\hline 4 & Imperial (Bonds Corner) & 6.4 & -1.1 & 24 & 25 & -0.5 & -0.5 \\
\hline 5 & Imperial (El Centro \#8) & 6.7 & 0.2 & 20.3 & 22.5 & 8.1 & -1.7 \\
\hline 6 & $\begin{array}{l}\text { Kobe, Japan(Nishi- } \\
\text { Akashi) }\end{array}$ & 20.53 & 22.8 & 48.3 & 49.9 & 19.9 & 54.3 \\
\hline 7 & $\begin{array}{c}\text { Kobe, } \\
\text { Japan(Takarazuka) }\end{array}$ & 12.1 & 19 & 38.4 & 41.5 & 18.5 & 2037 \\
\hline 8 & Landers & 11.3 & 12.2 & 28 & 28 & 11.4 & 39 \\
\hline 9 & Loma Prieta (Corralitos) & 16.5 & -8.2 & 47.3 & 49.5 & -6.7 & -33.1 \\
\hline 10 & Loma Prieta (LGPC) & 13.86 & -5.7 & 58.4 & 61.2 & -6 & -8.7 \\
\hline 11 & Mammoth Lakes & 0.01 & 0.004 & 6.1 & 6.1 & 0 & 0.08 \\
\hline 12 & Manjil, Iran & 16.1 & 13.9 & 67 & 73.2 & 11.3 & -45 \\
\hline 13 & Morgan Hill & 2.2 & 9.3 & 29.2 & 36.4 & 8.98 & 10 \\
\hline 14 & $\begin{array}{l}\text { N. Palm Springs(Noth } \\
\text { Palm) }\end{array}$ & 1.6 & 4.8 & 21.1 & 22.3 & 4.62 & 5.3 \\
\hline 15 & $\begin{array}{c}\text { N. Palm } \\
\text { Springs(Whitewater) }\end{array}$ & 8.1 & -7.6 & 47.5 & 47.2 & -8.7 & -9 \\
\hline 16 & Nahanni, Canada & 21.5 & -7.7 & 107.1 & 107.5 & -11.9 & -5.1 \\
\hline 17 & $\begin{array}{l}\text { Northridge-01 (Beverly } \\
\text { Hills) }\end{array}$ & 5.4 & -0.4 & 33.2 & 37 & -1.3 & 2.1 \\
\hline 18 & Northridge-01 (Castaic) & 0.15 & -0.5 & 17.6 & 18.8 & -0.1 & -0.2 \\
\hline 19 & $\begin{array}{l}\text { Northridge-01 } \\
\text { (Newhall) }\end{array}$ & 21.4 & -13.3 & 61.4 & 63.3 & -14.3 & -56 \\
\hline 20 & $\begin{array}{l}\text { ChiChi-Taiwan } \\
\text { (CHY028) }\end{array}$ & 6.6 & 3.7 & 17.9 & 17.9 & 3.7 & -12.2 \\
\hline 21 & $\begin{array}{l}\text { Northridge-01(Pardee- } \\
\text { SCE) }\end{array}$ & 10.6 & 3.6 & 37.7 & 41.7 & 3.4 & 4.3 \\
\hline 22 & Northridge-01 (Rinaldi) & 50 & 7.5 & 97 & 104.9 & 7.5 & 12.2 \\
\hline 23 & Northridge-01 (Santa) & 6.6 & -3.7 & 18 & 20.2 & -3.6 & -4.1 \\
\hline 24 & Northridge-01 (Simi) & 11.5 & 6.1 & 23.5 & 25.6 & 5.9 & -90.5 \\
\hline
\end{tabular}




\section{Civil Engineering Research Journal}

\begin{tabular}{|c|c|c|c|c|c|c|c|}
\hline 25 & Northridge-01 (Sylmar) & 18.3 & 5.7 & 43 & 48.3 & 5.4 & 121.6 \\
\hline 26 & $\begin{array}{c}\text { Northridge-01 } \\
\text { (Tarzana) }\end{array}$ & 27.7 & 16.1 & 55.3 & 64.7 & 16 & 34.4 \\
\hline 27 & Northridge-06 & 33 & 15 & 61.5 & 65.4 & 22 & 35 \\
\hline 28 & $\begin{array}{c}\text { ChiChi-Taiwan } \\
\text { (CHY029) }\end{array}$ & 1.9 & -4.8 & 13.3 & 12.5 & -5.4 & -14.1 \\
\hline 29 & San Salvador & 17.8 & -1.2 & 37 & 41.4 & -0.7 & 11.5 \\
\hline
\end{tabular}

Effect of Vertical Seismic Component on the Isolator

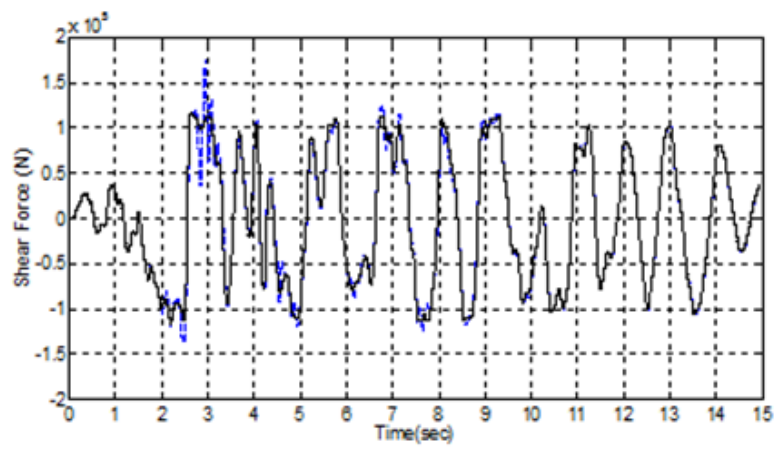

Figure 11: Shear force of isolator under 2D (solid line) and 3D (dashed) input cases (Northridge01-Rinaldi-1994).

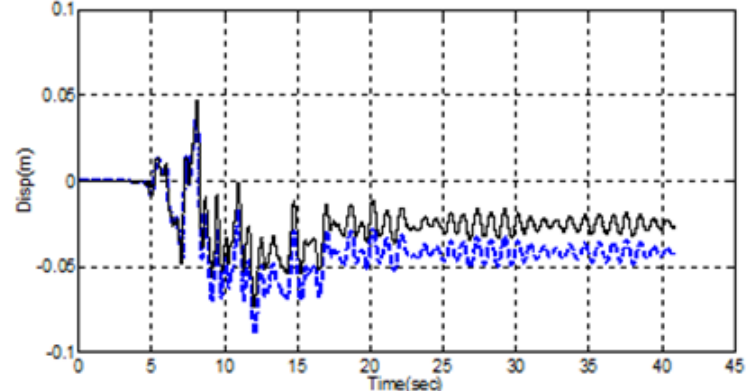

Figure 12: Shear force of isolator under 2D (solid line) and 3D (dashed) input cases (Northridge01-Rinaldi-1994).

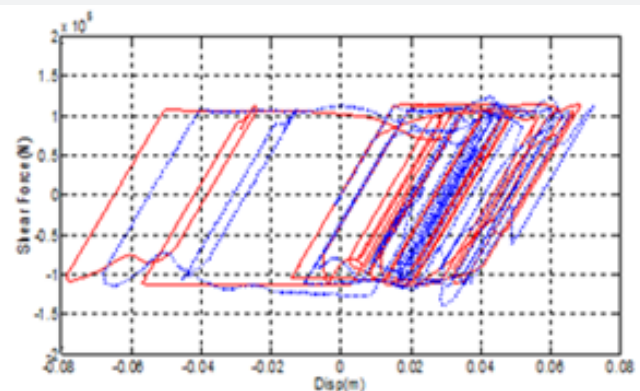

(a) Nahanni-Site1-1985.

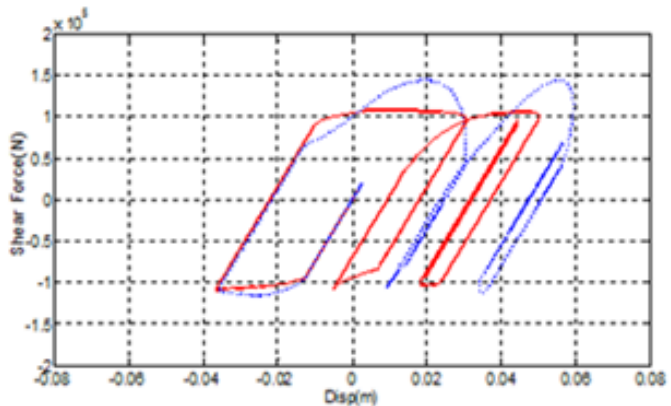

(c) Northridge-06-Rinaldi -1994.

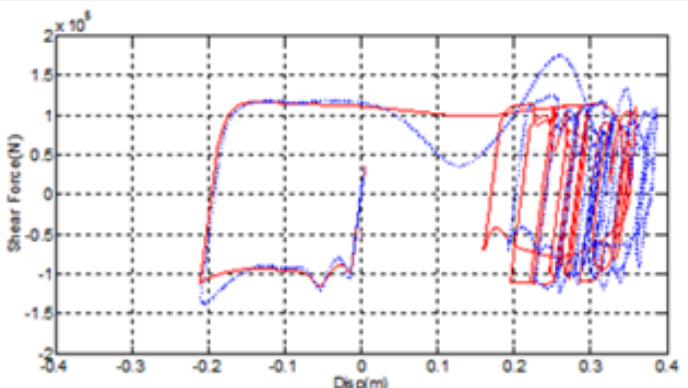

(b) Northridge-01-Rinaldi-1994

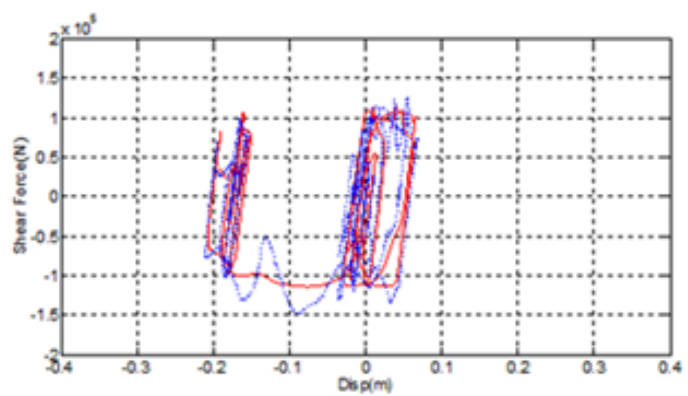

(d) Gazil-Karakyr-1976.

Figure 13: Force-displacement of isolators on pier under 2D (solid line, red) and 3D (dashed, blue) input. 
The increase in the maximum values of the shear force and relative displacement of the isolators under each seismic excitation as $\alpha$ F-Iso-P and $\alpha$ D-Iso-P are presented in Table 6. The time history diagrams of shear force and relative displacement of the isolator on the pier under the Northridge 01 (Rinaldi-1994) and Kobe-Japan (Nishi Akashi-1995) ground motions are shown in Figure $11 \& 12$.

According to Table 6, under all ground motions, the presence of vertical seismic component increases the maximum shear force. Thus, ignoring the vertical seismic component in the analysis means utter disregard to the increase in the isolator's shear force, which may reach as high as $50 \%$ under a ground motion similar to Northridge-01 (Rinaldi). The results obtained under a number of ground motions also show an increase in the maximum relative displacement after introducing the vertical seismic component. The most severe case in this regard is the $23 \%$ increase in this response parameter under the Kobe (NishiAkashi) ground motions.

For better evaluation of isolation performance, the forcedisplacement graphs of base isolators on the pier subjected to four different earthquake records are presented in Figure 13. As can be observed, the presence of vertical seismic component is generally similar, but sometimes the presence of vertical seismic component has caused a significant increase or decrease in the shear force. This change in shear force is due to momentary changes in the friction coefficient and axial force. This is induced by variation of vertical acceleration. In the presence of vertical seismic component, axial force of the base isolator undergoes wide-range changes. For example, the minimum and maximum axial forces obtained under the Gazil-Karakyr-1976 ground motions are $25 \mathrm{KN}$ and $3,035 \mathrm{KN}$. The response values under Northridge-01-Rinaldi-1994 earthquake record are 273KN and 3,026KN, respectively. These Figures indicate a 120 times increase in axial force under the former ground motions and an 11 times increase in this force under the latter case, which are all reflected in the occasionally erratic changes in the plots of Figure 13 \& 13. Figure 13 also shows a permanent displacement in the isolator under the Northridge-01-Rinaldi ground motion, which is evident from its curve moving rightward.

Comparing the maximum shear force of the base isolator under the 3D ground excitation with the design sliding force. Table 3 shows that under the Northridge-01-Rinaldi ground motions, the maximum actual shear force in the isolator exceeds the sliding force considered for the isolator in the design. For the isolators resting on the abutment, the calculated maximum shear force in all earthquakes except Manjil-Iran exceed the design value. This reflects the greater magnitude of the force transferred from the superstructure to the substructure and the force at which the deck slides over the isolators compared with the values considered in the design.

As mentioned in the introduction of AASHTO (2010), the vertical seismic component is ignored in design process. To investigate the effect of vertical seismic component on axial force of isolators, the change of this force due to introducing the vertical component is calculated. The $\alpha-\mathrm{N}-\mathrm{F}-\mathrm{Pier}$ and $\alpha-\mathrm{N}-\mathrm{F}-$ Abu parameters for the isolators seated on the mid-span base and the abutments are shown in Table 6.

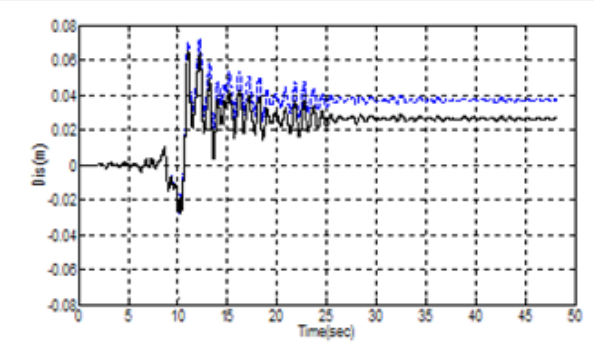

(a)

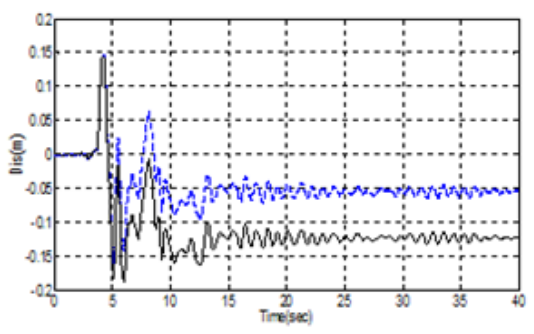

(c)

Figure 14: The time history diagrams of deck displacement both in absence (solid line, red) and presence (dashed, blue) of vertical component. 


\section{Civil Engineering Research Journal}

As shown in Table 6, introducing the vertical components of earthquake have made significant changes in the axial force. This doubling of the axial force in isolators indicates the possibility of buckling-induced instability of devices. The parameter then must be controlled according to Equation 5. It can be observed that $\alpha$-N-F-Pier parameter reaches about $107 \%$ in Nahani, Canada earthquake. $\alpha-\mathrm{N}-\mathrm{F}-\mathrm{Abu}$ also increased to $113 \%$ in Gazli, USSR earthquake. To demonstrate the effect of vertical component of earthquakes on the lateral and permanent displacement of the deck, the time history diagrams of deck displacement both in absence and presence of vertical seismic component of four ground motions are plotted in Figure 14. Appearance of larger residual displacement when the vertical component is applied, can be observed at the end of displacement time histories in these Figures. Considering the flexible behavior and partlyirreversible displacement of friction-rubber isolators, the maximum horizontal displacement and permanent displacement of the deck in the absence and presence of vertical seismic component were investigated. The results obtained from this investigation are presented in Table 6.

According to the data Table 6, shows an increase of both permanent and transient deck displacement in some case. This means that, absence of vertical seismic component in the analysis may result in underestimating the horizontal and permanent displacement of the deck. Comparing the values of $\alpha$ D-Iso-P and $\alpha$ Dis-Deck shows that presence of vertical seismic component affects the deck displacement more strongly than it does the relative displacement of isolator. The results show that introducing the vertical seismic component of Northridge-06 (Tarzana) ground motions has increased the deck maximum lateral displacement by $22 \%$, while introducing the vertical seismic component of Kobe-Japan (Takarazuka) earthquake has increased the deck permanent displacement by more than $2000 \%$. A significant sliding in the bridge deck also can be observed at the moments of sharp increase in the vertical seismic component (which usually coincides with a sharp increase in the horizontal acceleration). Due to absence of any self-restoration mechanism in the sliding part of the device, such earthquakeinduced displacements are permanent. For example, Figure 14 shows that the maximum permanent displacement induced by the Northridge-01 (Tarzana) ground motion is about $40 \mathrm{~cm}$, which undermines the post-earthquake serviceability and utility of the bridge.

\section{Spectral Analysis and Correlation of Data}

The natural vibration mode with a significant effect on vertical direction was identified. The correlation of the response parameters with the spectral values of vertical ground motion component at the period of this significant mode was evaluated. The response spectra of vertical component of all 29 ground motion were already depicted in Figure 8. The effective vibration mode of the model in vertical direction is the sixth mode with a

period of $T_{6}=0.15 \mathrm{sec}$. The spectral acceleration at $=0.15 \mathrm{sec}$

$\left(S_{a-0.15}\right.$ ) obtained under 29 ground motions are given in Table 7. The $\alpha \mathrm{N}$ for the axial force of the isolators on the pier and

abutment, as a result of changes in $S_{a-0.15}$ are show in Figure $15 \& 16$, respectively.

A linear regression can be reasonably applied to the data. Having the resulted regression equations and Equation 6, the result of response parameters including the effects of vertical motion can be estimated.

Table 7: The vertical spectral acceleration at $T_{6}=0.15$.

\begin{tabular}{|c|c|c|}
\hline No. & Earthquake & $S_{a-0.15}(g)$ \\
\hline 1 & Duze,Turkey(Bolu) & 0.46 \\
\hline 2 & Duze, Turkey(Lamont 375) & 0.43 \\
\hline 3 & Gazli, USSR & 1.8 \\
\hline 4 & Imperial (Bonds Corner) & 0.83 \\
\hline 5 & Imperial (El Centro \#8) & 0.59 \\
\hline 6 & Kobe, Japan(Nishi-Akashi) & 0.71 \\
\hline 7 & Kobe, Japan(Takarazuka) & 0.91 \\
\hline 8 & Landers & 0.82 \\
\hline 9 & Loma Prieta (Corralitos) & 0.7 \\
\hline 10 & Loma Prieta (LGPC) & 1.14 \\
\hline 11 & Mammoth Lakes & 0.13 \\
\hline 12 & Manjil, Iran & 1.34 \\
\hline 13 & Morgan Hill & 0.73 \\
\hline 14 & N. Palm Springs(Noth Palm) & 0.61 \\
\hline 15 & N. Palm Springs(Whitewater) & 1.37 \\
\hline 16 & Nahanni, Canada & 1.24 \\
\hline 17 & Northridge-01 (Beverly Hills) & 0.78 \\
\hline 18 & Northridge-01 (Castaic) & 0.49 \\
\hline 19 & Northridge-01 (Newhall) & 1.07 \\
\hline 20 & ChiChi-Taiwan (CHY028) & 0.4 \\
\hline 21 & Northridge-01 (Pardee-SCE) & 0.9 \\
\hline 22 & Northridge-01 (Rinaldi) & 1.97 \\
\hline 23 & Northridge-01 (Santa) & 0.47 \\
\hline 24 & Northridge-01 (Simi) & 0.72 \\
\hline 25 & Northridge-01 (Sylmar) & 1.1 \\
\hline 26 & Northridge-01 (Tarzana) & 1.65 \\
\hline 27 & Northridge-06 & 1.32 \\
\hline 28 & ChiChi-Taiwan (CHY029) & 0.3 \\
\hline 29 & San Salvador & 1 \\
\hline
\end{tabular}




\section{Civil Engineering Research Journal}
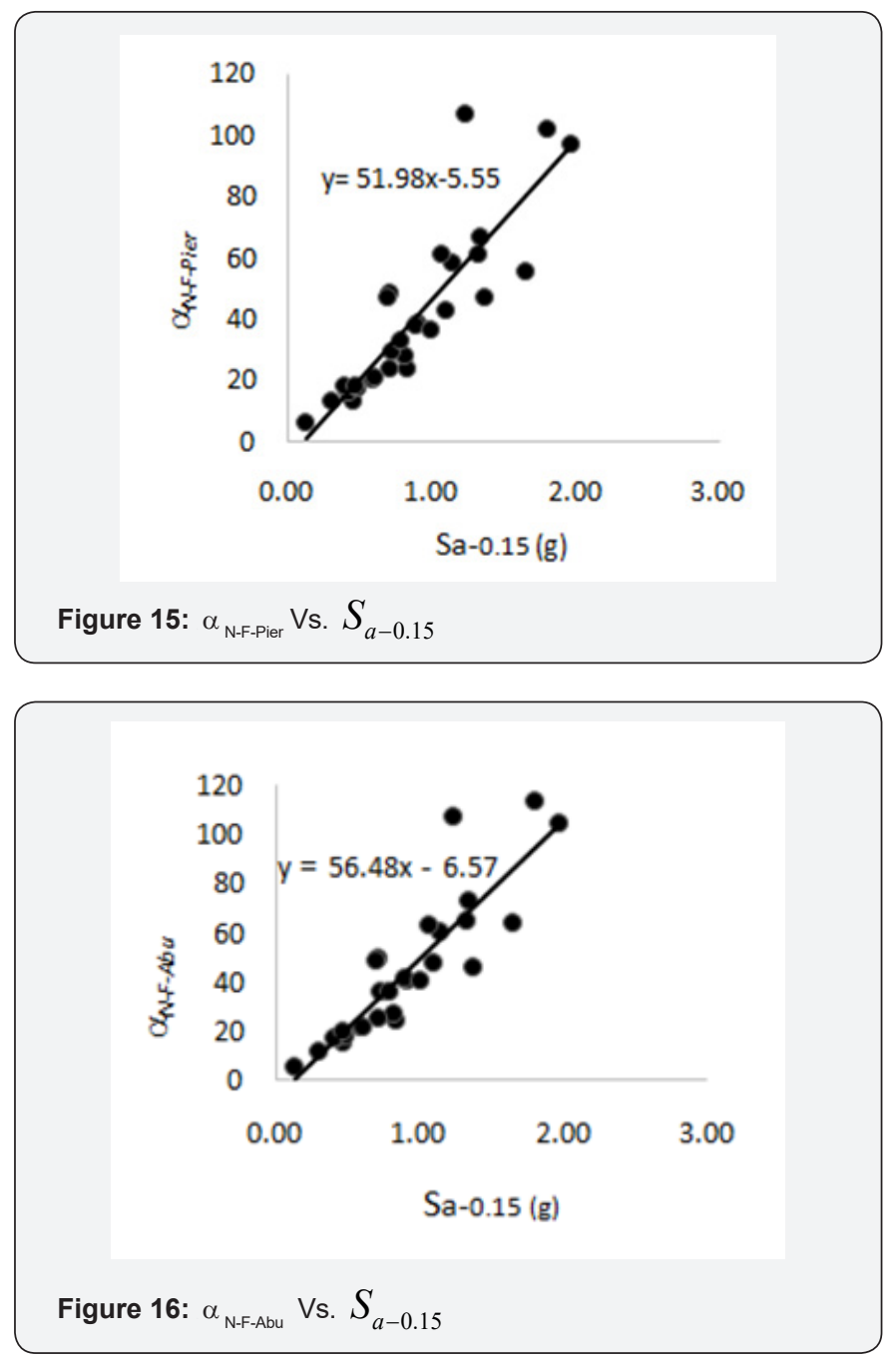

\section{Conclusion}

Despite the significant effect of vertical seismic component on the performance of isolation systems and structures located in near-fault areas, some of the design guidelines and regulations ignore the effect of this component on the base isolated structures. In this study, AASHTO (2010) guidelines were used to design a friction-rubber isolation system for a $51 \mathrm{~m}$ long two-span highway bridge. The structure was modeled in the OpenSees software. The method developed by Dao was then used to ensure the accurate modeling of friction coefficient changes versus the changes in vertical force and sliding velocity. To investigate the effect of vertical seismic component on the base isolated bridge, deck permanent and transient displacement and axial force demand on the isolator device was investigated. The analysis under 29 seismic excitations with significant vertical components once with isolator and again without isolator was performed.

The results obtained from the analysis are concluded as follows:
Ignoring the vertical seismic component in the analysis means potentially ignoring up to $50 \%$ increase in the maximum shear force.

As observed in Table 3, when introduced to the model, vertical seismic component caused the shear force to exceed the values specified in the isolator design guidelines. This means the force that will be transferred from the superstructure to the substructure and the force at which the deck may slide over the isolators may be greater than the design values.

The force-displacement curves obtained once in the absence and again in the presence of vertical seismic component, occasionally exhibit some differences due to momentary but considerable changes in the friction coefficient or axial force.

Vertical component of all tested ground motions increased the axial force of isolator, sometime by up to 100 percent. The magnitude of increase highlights the importance of incorporating the effect of vertical seismic component into the isolator design. Despite the significant increase in the maximum axial force, isolator models in this study showed no sign of buckling.

Introducing the vertical component of ground motion records in some cases increased the relative displacement of the isolators and horizontal permanent and transient displacement of the deck.

The axial forces of isolators were found to be correlated with their corresponding spectral acceleration of vertical acceleration component and a correlation relationship was derived accordingly for the system under study.

\section{Acknowledgement}

This research was supported by International Institute of Earthquake Engineering and Seismology (IIEES). This support is gratefully acknowledged.

\section{References}

1. Papazoglou AJ, Elnashai AS (1996) Analytical and field evidence of the damaging effect of vertical earthquake ground motion. Earthquake engineering and structural dynamics 25(10): 1109-1138.

2. Gloyd SPE (1997) Design of ordinary bridges for vertical seismic acceleration. In Workshop on the National Representation of Seismic Ground Motion for New and Existing Highway Facilities pp. 277-290.

3. Kunnath SK, Abrahamson N, Chai YH, Erduran E, Yilmaz Z (2008) Development of guidelines for incorporation of vertical ground motion effects in seismic design of highway bridges.

4. Rahai A, Arezoumandi M (2008) Effect of vertical motion of earthquake on RC bridge pier. In The 14th World Conference on Earthquake Engineering, Beijing.

5. Naeim F, Kelly JM (1999) Design of seismic isolated structures: from theory to practice. John Wiley \& Sons, USA. 


\section{Civil Engineering Research Journal}

6. Nakajima K, Iemura H, Takahashi Y, Ogawa K (2000) Pseudo dynamic tests and implementation of sliding bridge isolators with vertical motion. In $12^{\text {th }}$ World Conference on Earthquake Engineering.

7. Iemura H, Jain SK, Taghikhany T (2004) Effect of Vertical Acceleration on Seismic Performance of Resilient Sliding Isolation Systems in Highway Bridges. Waseda University, Japan.

8. Mazza F, Vulcano A (2008) Effects of horizontal and vertical nearfault ground motions on the nonlinear dynamic response of rc buildings with different base-isolation systems. In $14^{\text {th }}$ World Conference on Earthquake Engineering pp. 11-30.

9. Warn GP, Whittaker AS (2008) Vertical earthquake loads on seismic isolation systems in bridges. Journal of structural engineering 134(11): 1696-1704

10. Reyhanoğulları NE, Akyüz U (2015) Vertical ground motion influence on seismically isolated \& unisolated bridges. challenge 1(3): 117-123.

11. Wang C, Zhao J, Zhu L, Bao Y (2016) Effects of vertical excitation on the seismic performance of a seismically isolated bridge with sliding friction bearings. Earthquake Engineering and Engineering Vibration 15(1): 187-196

12. American Association of State Highway and Transportation Officials (AASHTO) (2010) Guide Specifications for Seismic Isolation Design. United States of America.

13. PEER (2014) Open System for Earthquake Engineering Simulations (OpenSees). Version 2.4.5. Berkeley: Pacific Earthquake Eng Research Center, Univ of California, USA.
14. Mazzoni S, McKenna F, Scott MH, Fenves GL (2006) OpenSees command language manual. Pacific Earthquake Engineering Research (PEER) Center.

15. DC Kent, R Park (1971) Flexural members with confined concrete. Journal of the Structural Division 97(7): 1969-1990.

16. Simo JC, Hughes TJ (2006) Computational inelasticity (Vol. 7). Springer Science \& Business Media, New York, USA.

17. Jangid RS (2014) Introduction to earthquake engineering. Journals Related to Earthquake Engineering and Bureau of Indian Standard codes, IIT Bombay, India.

18. Dao ND, Ryan KL, Sato E, Sasaki T (2013) Predicting the displacement of triple pendulum ${ }^{\mathrm{TM}}$ bearings in a full-scale shaking experiment using a three-dimensional element. Earthquake Engineering \& Structural Dynamics 42(11): 1677-1695.

19. Mokha A, Constantinou MC, Reinhorn AM (1988) Teflon bearings in aseismic base isolation: experimental studies and mathematical modeling. National Center for earthquake engineering research, Buffalo, New York, USA.

20. Bowden FP, Tabor D (1964) The friction and lubrication of solids part II. Clarendon Press, Oxford, United Kingdom.

21. Kunnath SK, Erduran E, Chai YH, Yashinsky M (2008). Effect of near-fault vertical ground motions on seismic response of highway overcrossings. Journal of Bridge Engineering 13(3): 282-290.

22. American Society of Civil Engineers, ASCE (2014) Seismic Evaluation of Existing Buildings, ASCE/SEI 41-13.

\section{Your next submission with Juniper Publishers} will reach you the below assets

- Quality Editorial service

- Swift Peer Review

- Reprints availability

- E-prints Service

- Manuscript Podcast for convenient understanding

- Global attainment for your research

- Manuscript accessibility in different formats

( Pdf, E-pub, Full Text, Audio)

- Unceasing customer service

Track the below URL for one-step submission https://juniperpublishers.com/online-submission.php 